\title{
Estimasi laju penyerapan karbon atmosfer melalui proses pelarutan batuan karbonat di kawasan karst jonggrangan (studi kasus: SBT gua anjani)
}

\author{
Dicky Satria Dwiputra ${ }^{1}$ Tjahyo Nugroho Adji ${ }^{1}$ Aji Dwi Pratama ${ }^{1}$ Eko Haryono $^{1}$ \\ ${ }^{1}$ Kelompok Studi Karst, Fakultas Geografi, Universitas Gadjah Mada, Indonesia \\ * corresponding author \\ adji tjahyo@ugm.ac.id
}

\begin{abstract}
Bentuklahan karst memiliki peran penting dalam penyerapan gas karbon dioksida atmosfer (CO2) di atmosfer yang terjadi pada saat proses karstifikasi. Melalui proses denudasi kawasan karst di Indonesia, jumlah karbondioksida yang terserap diperkirakan mencapai 13.482 $\mathrm{Gg} \mathrm{CO}_{2} /$ tahun. Penelitian ini dilakukan di Kawasan Karst Jonggrangan yang meliputi Sungai Bawah Tanah (SBT) Gua Anjani. Tujuan dari penelitian ini adalah: (1) Mengetahui tingkat pelarutan mineral $\mathrm{CaCO}_{3}$ di SBT Gua Anjani; (2) Mengetahui laju penyerapan karbon dioksida atmosfer melalui proses pelarutan batuan karbonat di SBT Gua Anjani. Penelitian dilakukan selama periode Maret 2018 hingga Maret 2019. Data yang digunakan dalam penelitian ini, yaitu debit aliran, karakteristik kimia aliran, dan karakteristik fisik aliran. Keseluruhan data diperoleh melalui observasi dan pengukuran langsung dilapangan. Hasil penelitian menunjukkan tingkat pelarutan mineral $\mathrm{CaCO}_{3}$ di SBT Gua Anjani sebesar $48,10 \mathrm{~m}^{3} /$ tahun $/ \mathrm{km}^{2}$, sedangkan laju penyerapan karbon dioksida atmosfer di SBT Gua Anjani sebesar70,50 ton $/ \mathrm{km}^{2} /$ tahun.
\end{abstract}

\section{Pendahuluan}

Karbon dioksida atmosfer $\left(\mathrm{CO}_{2}\right)$ sebagai bagian dari gas rumah kaca memiliki kontribusi yang

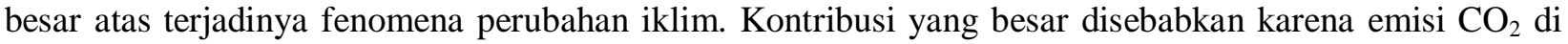
atmosfer terus meningkat hingga 70\% selama periode 1970-2004[1]. Bentuklahan karst memiliki peran penting dalam penyerapan gas karbon dioksida $(\mathrm{CO} 2)$ di atmosfer yang terjadi pada saat proses karstifikasi. [2]menyatakan bahwa keberadaan batuan karbonat mencakup luas area yang mencapai 22 juta $\mathrm{km}^{2}$ di duniaMenurut [3] keberadaan kawasan karst di seluruh kepulauan Indonesia mencapai \pm 140.000 $\mathrm{km}^{2}$ atau $20 \%$ dari total luas wilayah. Melalui proses denudasi kawasan karst di Indonesia, jumlah karbondioksida yang terserap diperkirakan mencapai $13.482 \mathrm{Gg} \mathrm{CO}_{2} /$ tahun [3]. Referensi[4] menyatakan bahwa untuk pelarutan batuan gamping, diperlukan 1 mol $\mathrm{CO}_{2}$ dalam pelarutan 1 mol $\mathrm{CaCO}_{3}$ dan untuk pelapukan dolomit, diperlukan $2 \mathrm{~mol} \mathrm{CO}_{2}$ dari atmosfer untuk melarutkan $1 \mathrm{~mol} \mathrm{CaMg}\left(\mathrm{CO}_{3}\right)_{2}$. Luas karst 
global, yaitu kurang lebih 2,2×107 $\mathrm{km}^{2}$ yang setara dengan $15 \%$ luas daratan di bumi dan memiliki penyerapan karbon residual dalam daratan yang mencapai 2,5 $\mathrm{Pg} \mathrm{C} \mathrm{yr}^{-1}$ [5], [6].

Sungai Bawah Tanah (SBT) Gua Anjani merupakan bagian dari Kawasan Karst Jonggrangan yang memiliki potensi untuk menyerap karbon dioksida atmosfer $\left(\mathrm{CO}_{2}\right)$. Penyerapan karbon dioksida atmosfer $\left(\mathrm{CO}_{2}\right)$ di kawasan karst terjadi pada saat proses karstifikasi di mana terdapat kontak antara $\mathrm{CO}_{2}$ terlarut, aliran air, dan batuan karbonat yang menyebabkan terjadinya proses pelarutan terhadap batuan karbonat di dalam akuifer karst. Oleh karena itu, perhitungan laju penyerapan karbon dioksida atmosfer $\left(\mathrm{CO}_{2}\right)$ di kawasan karst tidak terlepas dari proses pelarutan mineral $\mathrm{CaCO}_{3}$ yang terdapat di dalam akuifer karst tersebut. Berdasarkan latar belakang tersebut, tujuan dari penelitian ini, yaitu (1) mengetahui tingkat pelarutan mineral $\mathrm{CaCO}_{3}$ di SBT Gua Anjani dan (2) mengetahui laju penyerapan karbon dioksida atmosfer melalui proses pelarutan batuan karbonat.

\section{Metode}

\subsection{Lokasi Kajian}

Penelitian ini dilakukan di SBT Gua Anjani (Gambar 1). Lokasi penelitian ini secara administratif terletak di Desa Tlogoguwo, Kecamatan Kaligesing, Kabupaten Purworejo, Jawa Tengah. SBT Gua Anjani dimanfaatkan oleh masyarakat sekitar untuk memenuhi kebutuhan sehari-hari. SBT Gua Anjani merupakan SBT yang terletak di Kawasan Karst Jonggrangan. Berdasarkan perekaman data melalui tiga stasiun hujan yang meliputi stasiun Girimulyo, Stasiun Kaligesing, dan Stasiun Samigaluh, rerata hujan tahunan di Kawasan Karst Jonggrangan mencapai 2546 mm/tahun. Kawasan Karst Jonggrangan memiliki musim kemarau pada bulan April-Oktober dan musim hujan pada bulan November-Maret. Suhu udara di Kawasan Karst Jonggrangan memiliki rerata tahunan, yaitu $26,07^{\circ} \mathrm{C}$ dengan suhu maksimal mencapai $27,05^{\circ} \mathrm{C}$ dan suhu minimal mencapai $24,35^{\circ} \mathrm{C}$.

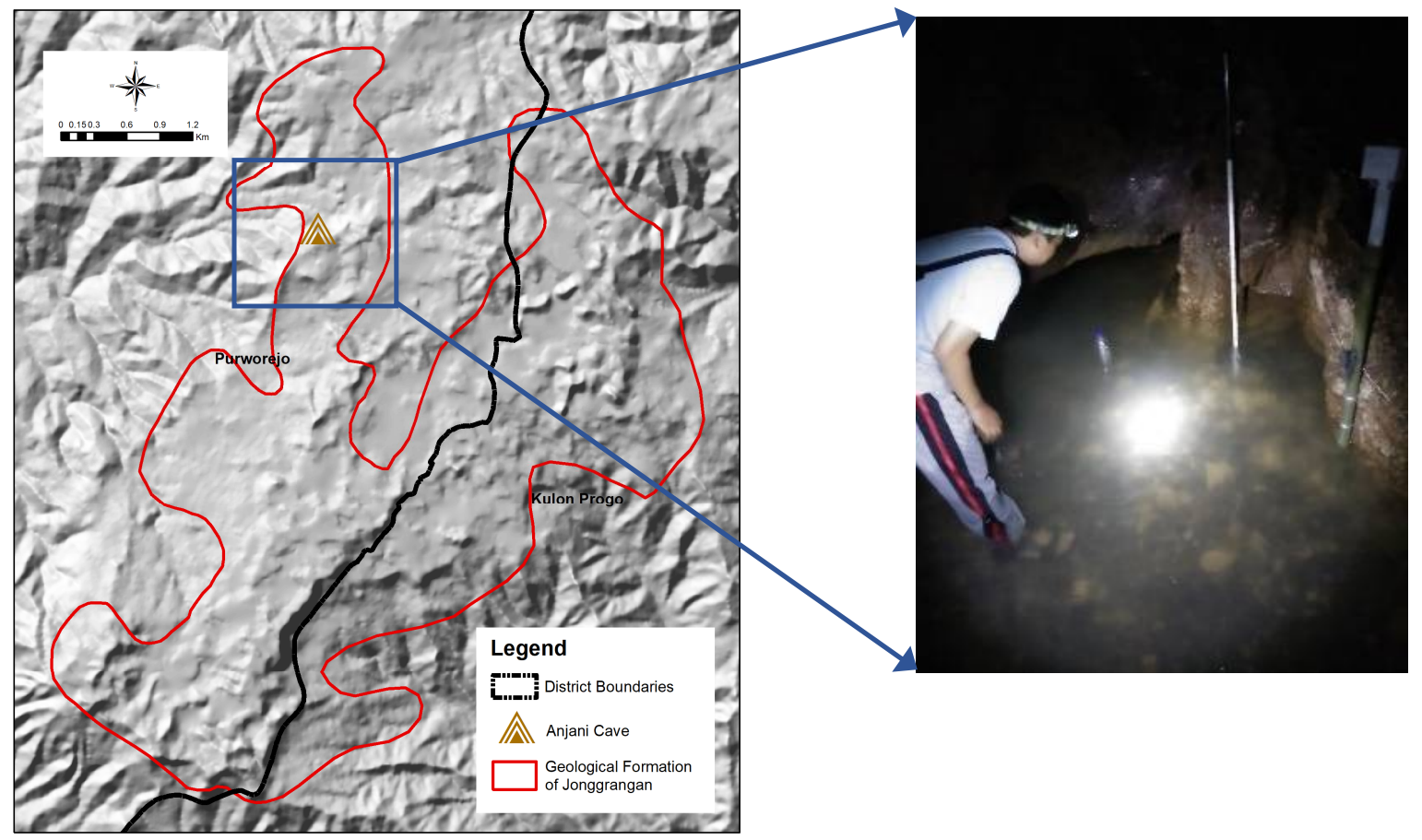

Gambar 1. Lokasi Sungai Bawah Tanah (SBT) Anjani 
Berdasarkan pembagian zona fisiografi Pulau Jawa oleh referensi [7], lokasi penelitian terletak di Zona Depresi Tengah Jawa untuk bagian Kabupaten Purworejo, sedangkan bagian Kabupaten Kulonprogo terletak di Pegunungan dan Kubah Zona Depresi Tengah Jawa.Pegunungan Kulonprogo terbentuk dari Gunungapi Purba Gadjah, Gunungapi Purba Idjo, dan Gunungapi Purba Menoreh atau yang dikenal dengan "Kubah Oblong" karena kubahnya yang memanjang dari Timur Laut hingga Barat Daya dengan panjang yang mencapai 32 kilometer dan lebar yang mencapai 15-20 kilometer [8]. Litologi di lokasi kajian sangat dipengaruhi oleh material berupa breksi basaltic andesities yang dikeluarkan oleh Gunungapi Purba Gadjah. Stratigrafi Pegunungan Kulonprogo (tabel 3.3), secara regional, dari yang paling tua hingga yang paling muda tersusun atas Kawasan Vulkanik Tua yang mencakup Batuan Sedimen Formasi Nanggulan dan batuan vulkanik dari Formasi Kebobutak (Formasi Andesit Tua), serta endapan laut dangkal Formasi Jonggrangan dan Formasi Sentolo[9].

Penggunaan lahan yang berada di Kawasan Karst Jonggrangan cukup variatif. Beberapa penggunaan lahan yang dapat dijumpai berupa permukiman, kebun campuran, tegalan, sawah tadah hujan, rumput, dan semak belukar. Kebun campuran dan semak belukar merupakan penggunaan lahan yang mendominasi di daerah penelitian. Jenis komoditas yang dapat dijumpai di Kawasan Karst Jonggrangan berupa pisang, kelapa, kopi, dan komoditas lainnya. Tabel 1 menunjukan jenis beserta luasan penggunaan lahan di Kawasan Karst Jonggrangan.

Tabel 1. Jenis

$$
\begin{gathered}
\text { Penggunaan lahan } \\
\text { Jonggrangan }
\end{gathered}
$$

\begin{tabular}{ccc}
\hline No. & Penggunaan Lahan & Luasan $(\mathrm{Ha})$ \\
\hline 1 & Kebun & 36136 \\
2 & Permukiman & 365,1 \\
3 & Tegalan & 125 \\
4 & Sawah tadah hujan & 13,3 \\
5 & Semak belukar & 1566 \\
6 & Rumput & 28,01 \\
\hline
\end{tabular}

dan Luasan di Kawasan Karst

\subsection{Alat dan Bahan}

Bahan yang digunakan dalam penelitian ini, yaitu terdiri dari peta Rupa Bumi Indonesia (RBI) skala 1:25.000, peta Geologi Lembar Yogyakarta skala 1:100.000, dan citra satelit. Bahan-bahan tersebut digunakan untuk membuat peta lokasi penelitian. Alat yang digunakan dibedakan berdasarkan tahapan penelitian, yaitu tahapan persiapan, pengumpulan data dan tahapan pengolahan data. Tahapan persiapan mengunakan alat berupa software ArcGIS 10.3 untuk mengolah data-data geospasial sehingga dihasilkan output berupa peta preliminary untuk observasi lapangan. Tahapan pengumpulan data menggunakan alatalat yang meliputi pengukuran debit aliran, karakteristik fisik aliran, dan karakteristik kimia aliran. Pengukuran debit aliran menggunakan alat berupa current meter, yallon, pita ukur, penunjuk waktu, dan Automatic Water Level Data Logger. Alat yang digunakan untuk mengukur karakteristik fisik aliran, yaitu water checker, sedangkan untuk mengukur karakteristik kimia aliran menggunakan alkalinity test kit. Tahapan pengolahan data menggunakan alat-alat berupa software hoboware dan Microsoft excel untuk mengolah data-data yang didapatkan saat di lapangan berupa data debit aliran, karakteristik fisik aliran, dan karakteristik kimia aliran.

\subsection{Menghitung Tingkat Pelarutan Mineral $\mathrm{CaCO}_{3}$}

Perhitungan tingkat pelarutan mineral $\mathrm{CaCO}_{3}$ menggunakan rumusperhitungan yang diperkenalkan oleh Balazs (1968). Perhitungan tingkat pelarutan mineral $\mathrm{CaCO}_{3}$ menurut Balazs (1968) dibedakan 
berdasarkan komponen daerah tangkapan air (DTA). SBT Gua Anjani memiliki Daerah Tangkapan Air (DTA) berupa sungai allogenic. Oleh karena itu, rumus yang digunakan adalah:

$$
\mathrm{K}_{\mathrm{s} 2}=\left(\left(\mathrm{Q}_{2} \cdot \mathrm{T}_{2}\right)-\left(\mathrm{Q}_{1} \cdot \mathrm{T}_{1}\right)\right) / \mathrm{f} . \mathrm{t}_{2}
$$

Keterangan:

$\mathrm{K}_{\mathrm{s} 2}=$ Tingkat pelarutan mineral $\mathrm{CaCO}_{3}\left(\mathrm{~m}^{3} /\right.$ year $\left./ \mathrm{km}^{2}\right)$

$\mathrm{Q}_{2} \quad=$ Debit aliran di zona karst $\left(\right.$ million $\left.\mathrm{m}^{3}\right)$

$\mathrm{T}_{2} \quad=$ Kandungan mineral $\mathrm{CaCO}_{3}$ terlarut di zona karst $(\mathrm{mg} / \mathrm{l})$

$\mathrm{Q}_{1}=$ Debit aliran di zona non-karst (DTA) (million $\mathrm{m}^{3}$ )

$\mathrm{T}_{1} \quad=$ Kandungan mineral $\mathrm{CaCO}_{3}$ terlarut di zona non-karst (DTA) $(\mathrm{mg} / \mathrm{l})$

$\mathrm{f} \quad=$ Berat spesifik rata-rata batuan karbonat $(2,5)$

$\mathrm{t}_{2} \quad=$ Luas area karst $\left(\mathrm{km}^{2}\right)$

\subsection{Luas Daerah Tangkapan Air (DTA)}

Luas DTA dihitung menggunakan metode topografi, neraca air, dan nomogram. Metode topografi dilakukan dengan mendelineasi DTA berbasiskan topografi menggunakan software ArcGIS, metode neraca air menggunakan rumus sebagai berikut:

Keterangan:

$$
\mathrm{Q}=\mathrm{P}-\mathrm{E} \pm \Delta \mathrm{S}
$$

$\mathrm{Q}$ : debit runoff (m3/s atau liter/s)

$\mathrm{P}$ : presipitasi (mm/tahun)

E : evapotranspirasi (mm/tahun)

$\Delta \mathrm{S}:$ perubahan simpanan ( $\mathrm{mm} /$ tahun)

Penentuan luas DTA berdasarkan pendekatan nomogram (gambar 2) menggunakan variabel-variabel, seperti debit aliran dan hujan efektif.

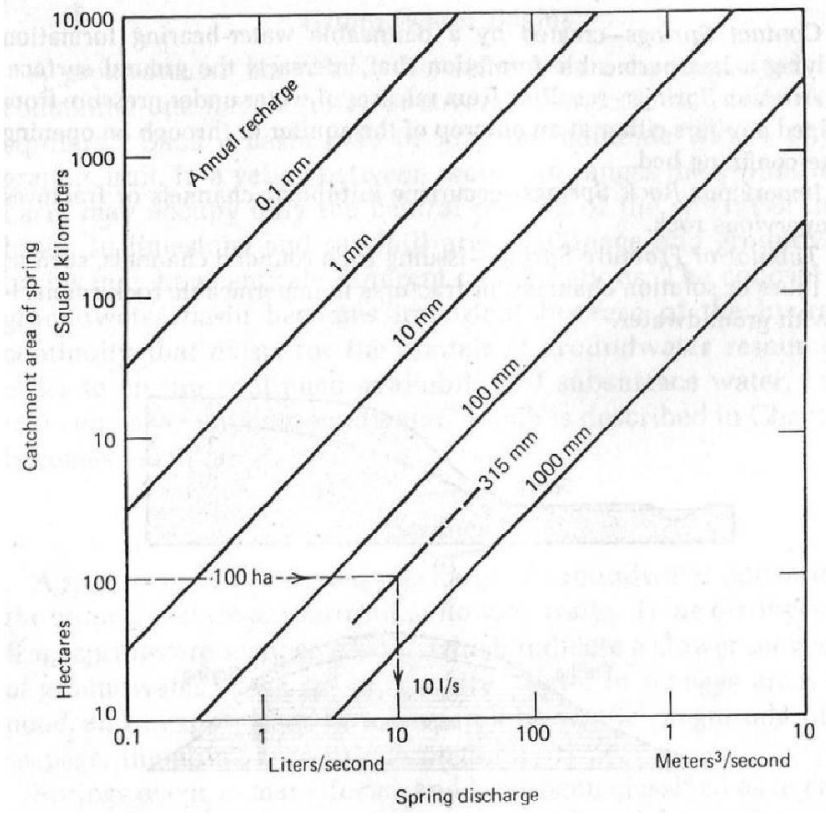


Gambar 2. Nomogram

\subsection{Menghitung Laju Penyerapan Karbon Dioksida Atmosfer Melalui Proses Pelarutan Batuan Karbonat}

Perhitungan Laju Penyerapan Karbon Dioksida Atmosfer Melalui Proses Pelarutan Batuan Karbonat menggunakan persamaan sebagai berikut:

$$
\mathrm{F}=1 / 2 \times \mathrm{HCO} 3 \times \mathrm{Q} \times(\mathrm{M} \mathrm{CO} 2 / \mathrm{M} \mathrm{HCO} 3)
$$

Keterangan:

$\begin{array}{ll}\mathrm{F} & =\text { Potensi Penyerapan Karbon (ton/tahun) } \\ \mathrm{HCO}_{3}{ }^{-} & =\text {Konsentasi HCO3 dalam air }(\mathrm{g} / \mathrm{l}) \\ \mathrm{Q} & =\text { Debit }(\mathrm{l} / \text { tahun }) \\ \mathrm{M} \mathrm{CO}_{2} & =\text { Berat Molekul }(\mathrm{Mr}) \mathrm{CO}_{2}(\mathrm{Mr}=44) \\ \mathrm{M} \mathrm{HCO}_{3}{ }^{-}=\text {Berat Molekul (Mr) } \mathrm{HCO}_{3}{ }^{-}(\mathrm{Mr}=61,02)\end{array}$

3. Hasil dan Pembahasan

3.1. Tingkat Pelarutan Mineral $\mathrm{CaCO}_{3}$ di SBT Gua Anjani

Sebagai suatu bentukan yang terbentuk di kawasan karst, SBT Gua Anjani dikontrol oleh berbagai proses, di antaranya adalah proses pelarutan mineral $\mathrm{CaCO}_{3}$. Berdasarkan hasil perhitungan yang ditampilkan pada Tabel 4.2, SBT Gua Anjani memiliki tingkat pelarutan mineral $\mathrm{CaCO}_{3}$ sebesar 48,1 $\mathrm{m}^{3} / \mathrm{km}^{2} /$ tahun. Debit aliran dan kandungan $\mathrm{CaCO}_{3}$ terlarut, sebagai variabel dalam perhitungan, menjadi faktor yang memengaruhi tingkat pelarutan mineral $\mathrm{CaCO}_{3}$. Total debit aliran di SBT Gua Anjani selama setahun mencapai $4,82 \times 10^{6} \mathrm{~m} / \mathrm{s}$, sedangkan rerata kandungan $\mathrm{CaCO}_{3}$ terlarut selama setahun mencapai $169,7 \mathrm{mg} / \mathrm{l}$. semakin tinggi total debit aliran dan rerata kandungan $\mathrm{CaCO}_{3}$ terlarut, semakin tinggi juga tingkat pelarutan mineral $\mathrm{CaCO}_{3}$ terlarut yang akan dihasilkan.

Tabel 1.Tingkat Pelarutan Mineral $\mathrm{CaCO}_{3}$ di Sungai Bawah Tanah (SBT) Gua Anjani

\begin{tabular}{|c|c|c|c|c|c|c|c|c|}
\hline Bulan & $\begin{array}{c}\text { Rata- } \\
\text { Rata } \\
\text { Debit } \\
\text { Bulan } \\
\text { an } \\
(\mathrm{L} / \mathrm{s})\end{array}$ & $\begin{array}{c}\text { Debit } \\
(\mathrm{Q} 2) \\
\left(\mathrm{x} 10^{6}\right. \\
\mathrm{m}^{3} / \mathrm{tah} \\
\text { un })\end{array}$ & $\begin{array}{c}\text { Rata- } \\
\text { Rata } \\
\text { CaCO3 } \\
\text { dalam } \\
\text { Setahun } \\
(\mathrm{T} 2) \\
(\mathrm{mg} / \mathrm{l})\end{array}$ & $\begin{array}{c}\text { Total } \\
\text { Debit } \\
\text { Sinking } \\
\text { Stream } \\
\text { dalam } \\
\text { Setahun } \\
\text { (x106 } \\
\mathrm{m}^{3} / \text { tahun) }\end{array}$ & $\begin{array}{c}\text { Rata-Rata } \\
\text { CaCO3 } \\
\text { sinking } \\
\text { stream } \\
\text { dalam } \\
\text { Setahun } \\
(\mathrm{T} 2) \\
(\mathrm{mg} / \mathrm{l}) \\
\end{array}$ & $\mathrm{f}$ & $\begin{array}{c}\text { Luas } \\
\text { Area } \\
\text { karst } \\
(\mathrm{t} 2) \\
\left(\mathrm{km}^{2}\right)\end{array}$ & $\begin{array}{c}\text { Tingkat } \\
\text { Pelarutan } \\
\text { Mineral } \\
\mathrm{CaCO}_{3} \\
(\mathrm{Ks} 2) \\
\left(\mathrm{m}^{3} / \text { Tahun/ }\right. \\
\left.\mathrm{Km}^{2}\right)\end{array}$ \\
\hline Mar-18 & 218,2 & & & & & & & \\
\hline Apr-18 & 173,3 & & & & & & & \\
\hline Mei-18 & 122,8 & & & & & & & \\
\hline Jun-18 & 80,9 & 4,82 & 169,70 & 2,72 & 137,50 & 2,50 & 3,69 & 48,10 \\
\hline Jul-18 & 63,0 & & & & & & & \\
\hline Aug-18 & 64,2 & & & & & & & \\
\hline Sep-18 & 67,9 & & & & & & & \\
\hline
\end{tabular}




\begin{tabular}{rr} 
Oct-18 & 63,0 \\
Nov-18 & 183,4 \\
Des-18 & 232,3 \\
Jan-19 & 333,6 \\
Feb-19 & 194,2 \\
Mar-19 & 218,9 \\
\hline
\end{tabular}

Faktor lainnya yang memengaruhi tingkat pelarutan mineral $\mathrm{CaCO}_{3}$ dalam suatu akuifer karst adalah karakteristik dari akuifer karst tersebut. Karakteristik yang memengaruhi di antaranya adalah $\mathrm{CO}_{2}$ terlarut, suhu dalam air, dan kondisi $\mathrm{pH}$ (tabel 3). Semakin tinggi kandungan $\mathrm{CO}_{2}$ terlarut atau $\mathrm{PCO}_{2}$ di dalam suatu akuifer karst, semakin tinggi juga tingkat pelarutan mineral $\mathrm{CaCO}_{3}$ yang akan terjadi, sedangkan suhu memiliki hubungan yang berbanding terbalik dengan tingkat pelarutan. Semakin rendah suhu, tingkat pelarutan mineral $\mathrm{CaCO}_{3}$ akan semakin tinggi dan sebaliknya. SBT Gua Anjani diketahui memiliki nilai $\mathrm{PCO}_{2}$ yang berkisar antara -2.53 hingga -1.29 dan memiliki rerata suhu tahunan sekitar $23,26^{\circ} \mathrm{C}$. Kondisi $\mathrm{pH}$ juga memengaruhi tingkat pelarutan di dalam akuifer karst, semakin rendah $\mathrm{pH}$ atau semakin asam kondisi aliran di dalam akuifer karst, tingkat pelarutan mineral $\mathrm{CaCO}_{3}$ yang terjadi akan semakin tinggi dan begitu juga sebaliknya. Hal ini sesuai dengan yang dikatan referensi[10]bahwa Semakin tinggi kandungan $\mathrm{CO}_{2}$ terlarut dan semakin rendah $\mathrm{pH}$, tingkat pelarutan mineral $\mathrm{CaCO}_{3}$ yang terjadi akan semakin tinggi. SBT Gua Anjani diketahui memiliki rerata pH, yaitu sekitar 7,42.

Tabel 3.PerbandinganTotal Debit Tahunan di Ketiga Lokasi Kajian

\begin{tabular}{ccrrr}
\hline SBT/Mataair & $\begin{array}{c}\text { Total Debit Tahunan } \\
(\mathbf{Q 2})\left(\mathbf{x 1 0}^{\mathbf{6}} \mathbf{~ m}^{\mathbf{3}} / \mathbf{s}\right)\end{array}$ & $\begin{array}{c}\text { Log } \\
\mathbf{P C O 2}\end{array}$ & $\begin{array}{c}\text { Rerata Suhu } \\
\text { Tahunan }\left({ }^{\circ} \mathbf{C}\right)\end{array}$ & $\begin{array}{c}\text { Rerata pH } \\
\text { Tahunan }\end{array}$ \\
\hline SBT Gua Anjani & 4,82 & $-2,53--1,29$ & 23,26 & 7,42
\end{tabular}

\subsection{Laju Penyerapan Karbon Dioksida Atmosfer Melalui Proses Pelarutan Batuan Karbonat}

Sungai Bawah Tanah (SBT) Gua Anjani memiliki imbuhan berupa allogenic recharge atau aliran permukaan yang masuk ke dalam sistem akuifer karst [15]. Aliran permukaan yang mengimbuh SBT Gua Anjani masuk melalui sinking stream. Aliran permukaan yang menjadi imbuhan SBT Gua Anjani, di antaranya adalah Jumbleng Sawah, Kali Cebong, dan Kali Setro (Gambar 3).
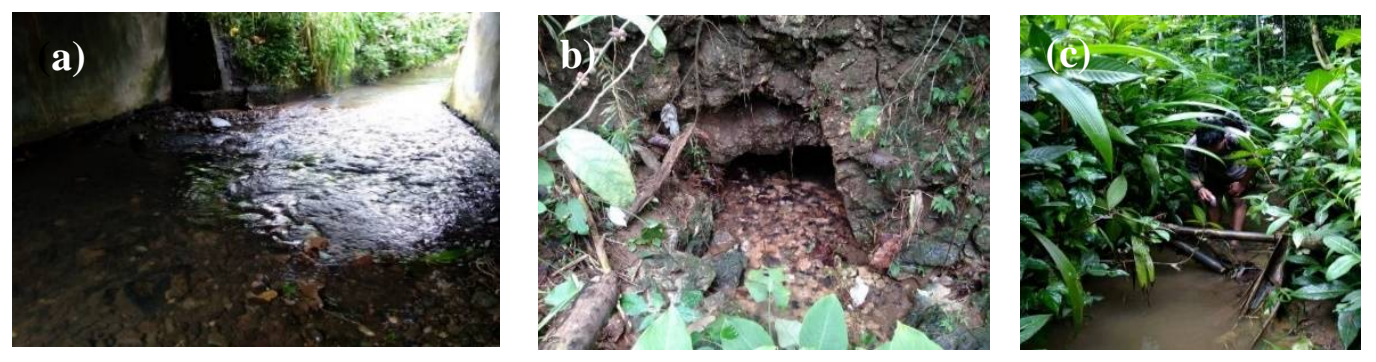

Gambar 3.Aliran Permukaan Kali Cebong (a), Jumbleng Sawah (b), da n Kali Setro (c) yang mengimbuh SBT Gua Anjani

Berdasarkan Tabel 4.11, laju penyerapan karbon dioksida atmosfer di SBT Gua Anjani mencapai $70,5 \mathrm{ton} / \mathrm{km}^{2} /$ tahun. Terdapat beberapa faktor yang memengaruhi nilai laju penyerapan karbon dioksida 
atmosfer di SBT Gua Anjani. Faktor-faktor tersebut di antaranya adalah besarnya rerata tahunan debit aliran dan juga konsentrasi $\mathrm{HCO}_{3}^{-}$.

Tabel 4.Laju Penyerapan Karbon dioksida atmosfer atmosfer di Sungai Bawah Tanah Gua Anjani

\begin{tabular}{ccccccc}
\hline Bulan & $\begin{array}{c}\text { Rata- } \\
\text { Rata } \\
\text { Debit } \\
\text { Bulan } \\
\text { an } \\
(\mathbf{l} / \mathbf{s})\end{array}$ & $\begin{array}{c}\text { Rata-Rata } \\
\text { Debit Tahunan } \\
\text { (l/tahun) }\end{array}$ & $\begin{array}{c}\text { Rata-Rata } \\
\text { Konsentra } \\
\text { si HCO } \\
\text { dalam } \\
\text { setahun } \\
\text { (g/l) }\end{array}$ & $\begin{array}{c}\text { Mr } \\
\mathbf{C O}_{2}\end{array}$ & $\begin{array}{c}\mathbf{M r} \\
\mathbf{H C O}_{3}\end{array}$ & $\begin{array}{c}\text { Laju Penyerapan } \\
\text { Karbon dioksida } \\
\text { atmosfer } \\
\text { (ton/km²/tahun) }\end{array}$ \\
\hline Mar-18 & 43,65 & & & & \\
Apr-18 & 34,67 & & & & \\
May-18 & 24,58 & & & & \\
Jun-18 & 16,20 & & & & \\
Jul-18 & 12,63 & & & & \\
Aug-18 & 12,86 & & & & \\
Sep-18 & 13,60 & 944998856,2 & & & \\
Oct-18 & 12,60 & & & & \\
Nov-18 & 36,68 & & & & \\
Dec-18 & 46,46 & & & & \\
Jan-19 & 66,72 & & & & \\
Feb-19 & 38,85 & & & & \\
Mar-19 & 43,80 & & & & & \\
\hline
\end{tabular}

Rerata tahunan debit aliran di SBT Gua Anjani berdasarkan tabel 4.11 mencapai 944998856,2 liter/tahun. Berdasarkan hasil observasi di lapangan, pada dasarnya, sistem akuifer SBT Gua Anjani memiliki sistem pelorongan (conduit) berkembang [16], [17]. Perkembangan dari suatu akuifer karst dapat ditinjau dari derajat karstifikasi dari sistem akuifer karst tersebut. Menurut referensi [11], derajat karstifikasi dari SBT Gua Anjani, yaitu 8 (complex discharge regime) dengan karstifikasi pada akuifer berkembang semakin tinggi serta terbentuk oleh saluran conduit yang berukuran besar. Sistem pelorongan yang telah berkembang menjadi ciri bahwa sistem akuifer karst tersebut telah jauh berkembang. Sistem pelorongan yang telah berkembang juga menyebabkan suatu SBT atau mataair akan memiliki debit puncak yang lebih besar.

Namun, meskipun memiliki debit puncak yang lebih besar diakibatkan adanya sistem pelorongan yang telah lebih berkembang, secara rerata tahunan SBT Gua Anjani memiliki debit aliran yang jauh lebih rendah. Terdapat beberapa faktor yang memengaruhi kecilnya rerata tahunan debit aliran di SBT Gua Anjani, di antaranya adalah luas daerah tangkapan air (DTA) dan debit sungai allogenic yang mengimbuh SBT Gua Anjani. Berdasarkan hasil penentuan luas DTA dengan menggunakan pendekatan neraca air dan topografi, Luas DTA SBT Gua Anjani secara berturut-turut hanya sekitar 3,69 $\mathrm{km}^{2}$ dan 3,43 $\mathrm{km}^{2}$. Perbedaan luas DTA melalui kedua pendekatan tersebut disebabkan oleh adanya perbedaan karakteristik antara atas dan bawah permukaan karst. Berkembangnya sistem pelorongan di bawah sistem karst menyebabkan sistem aliran di bawah permukaan jauh lebih berkembang. Kemungkinan adanya "kebocoran" dalam sistem akuifer karst juga menyebabkan adanya aliran yang masuk atau keluar dari 
sistem sehingga DTA tidak hanya terbatas berdasarkan topografi di atas permukaan karst saja, tetapi juga dapat melebihi batas DAS berbasiskan topografi tersebut.

Penentuan luas DTA menggunakan pendekatan neraca air dan topografi kemudian dianalisis ulang menggunakan pendekatan nomogram milik[12](Gambar 4). Penentuan luas DTA dengan menggunakan nomogramdilakukan melalui identifikasi hubungan antara rerata debit tahunan, imbuhan (presipitasi) tahunan, dan luas DTA. Presipitasi tahunan yang digunakan sebagai input dalam nomogram hanya $40 \%$ saja karena daerah penelitian merupakan kawasan karst dengan formasi yang didominasi batuan gamping. Hal ini sesuai dengan SNI 19-6728.1-2002 (2002) mengenai imbuhan tahunan berdasarkan keadaan formasi geologi, seperti yang ditampilkan pada Tabel 5. Berdasarkan hasil penentuan luas DTA melalui nomogram, diketahui bahwa luas DTA SBT Gua Anjani, yaitu sekitar $4 \mathrm{~km}^{2}$. Luas ini cukup mendekati dengan luas DTA SBT Gua Anjani berdasarkan pendekatan neraca air, yaitu sekitar $4 \mathrm{~km}^{2}$. Referensi [13] menyatakan bahwa karakteristik daerah tangkapan air (DTA) yang memengaruhi aliran, di antaranya adalah luas, bentuk, topografi, dan tata guna lahan. Referensi [14] juga menyatakan karakteristik drainase suatu DTA, seperti bentuk dan luas DTA, kerapatan drainase, serta intensitas curah hujan akan memengaruhi kondisi discharge dalam suatu akuifer.

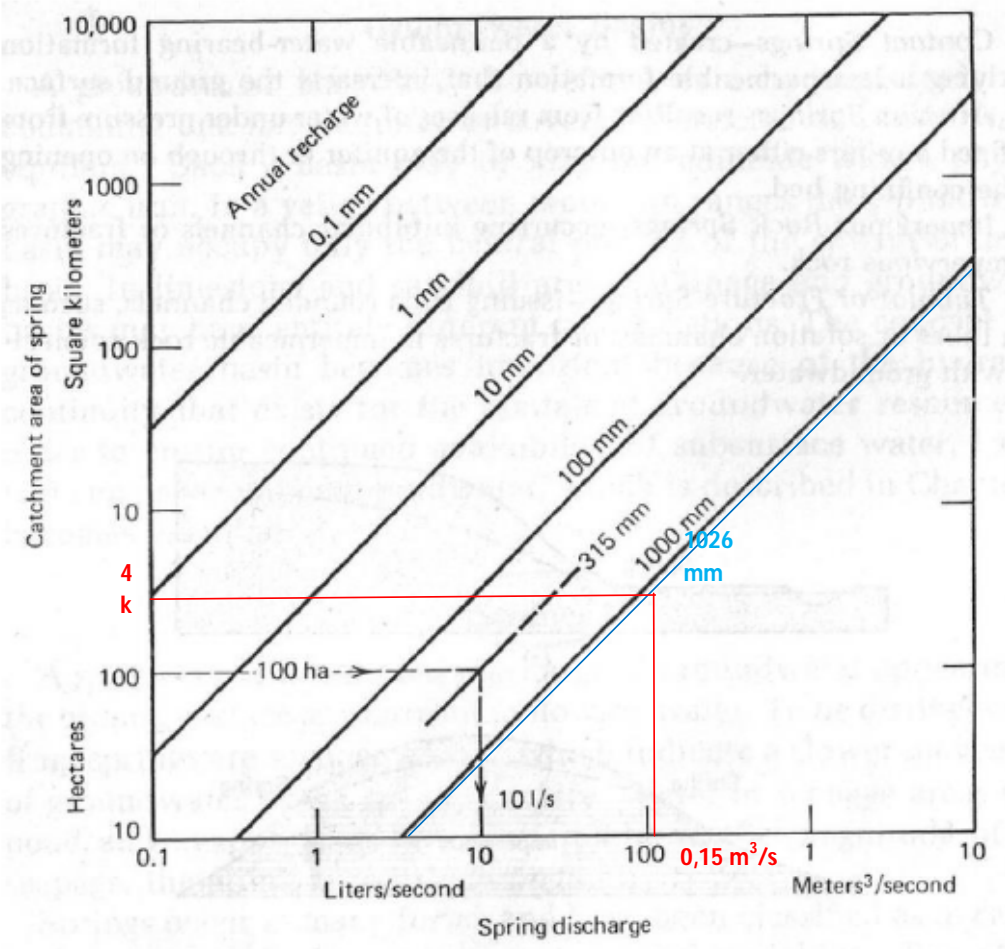

Gambar 4.Nomogram Sungai Bawah Tanah (SBT) Gua Anjani

Tabel 5.Persentase Imbuhan dan Curah Hujan Rata-Rata Berdasarkan Keadaan Formasi Geologi

\begin{tabular}{|c|r|}
\hline Formasi Geologi & Imbuhan RC (\%) \\
\hline Volkanik resen & $30-50$ \\
\hline Volkanik tua/sedimen/campuran sedimen resen & $15-25$ \\
\hline Sedimen terutama napal atau indurated rocks & 5 \\
\hline
\end{tabular}


Debit sungai allogenic atau sinking stream (Gambar 5) yang mengimbuh SBT Gua Anjani juga memengaruhi kondisi debit aliran di SBT Gua Anjani. Sungai allogenicKali Cebong, Jumbleng Sawah, dan Kali Setro memiliki rerata tahunan debit yang rendah, yaitu $1,6 \times 10^{6} \mathrm{~m}^{3} /$ tahun, $0,58 \times 10^{6} \mathrm{~m}^{3} /$ tahun, dan $0,55 \times 10^{6} \mathrm{~m}^{3} /$ tahun. Debit aliran yang rendah dari ketiga sinking stream tersebut dipengaruhi oleh lokasi dari ketiga sinking stream tersebut. Lokasi Jumbleng Sawah, Kali Cebong, dan Kali Setro berada di hulu dari DTA SBT Gua Anjani dan jaraknya berdekatan dengan SBT Gua Anjani, yaitu hanya sekitar 650 meter sehingga menyebabkan ketiga sinking stream tersebut cepat masuk ke dalam sistem akuifer SBT Gua Anjani tanpa terakumulasi terlebih dahulu dalam jumlah yang besar.

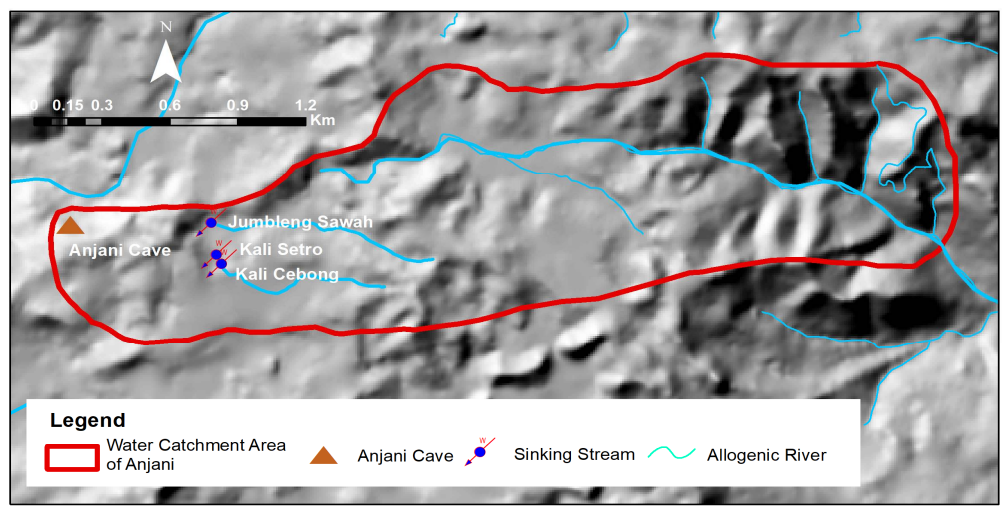

Konsentrasi $\mathrm{HCO}_{3}^{-}$juga sangat berpengaruh terhadap kemampuan suatu sistem akuifer dalam menyerap karbon dioksida atmosfer selain debit aliran. Rerata tahunan Konsentrasi $\mathrm{HCO}_{3}{ }^{-}$di SBT Gua Anjani memiliki nilai sebesar 0,21 gram/liter. Nilai Konsentrasi $\mathrm{HCO}_{3}{ }^{-}$sangat dipengaruhi oleh musim yang menyebabkan dinamika kondisi aliran di dalam sistem akuifer karst. Berdasarkan Gambar 6, konsentrasi $\mathrm{HCO}_{3}^{-}$akan meningkat ketika musim kemarau dibandingkan musim hujan. Hal ini dikarenakan aliran diffuse akan lebih mendominasi pada saat musim kemarau. Aliran diffuse yang berasal dari lapisan epikarst akan melarutkan batuan karbonat di dalam lapisan tersebut sehingga ketika aliran tersebut mengimbuh sungai bawah tanah, aliran tersebut sudah dalam keadaan jenuh dan memiliki tingkat konsentrasi $\mathrm{HCO}_{3}{ }^{-}$yang tinggi [18]. Minimnya aliran conduit pada musim kemarau juga menyebabkan kondisi aliran menjadi lebih jenuh dan konsentrasi $\mathrm{HCO}_{3}{ }^{-}$cenderung lebih stabil.

Konsentrasi $\mathrm{HCO}_{3}^{-}$secara rerata tahunan cenderung rendah. Kondisi demikian disebabkan oleh karakteristik dari SBT Gua Anjani yang merupakan sistem karst allogenic. Sistem karst allogenic mendapat input aliran dari sungai allogenic yang berasal dari wilayah non-karst. Sungai allogenic yang meng-input suatu akuifer karst juga biasa disebut sebagai sinking stream. Sungai allogenic cenderung memiliki nilai konsentrasi $\mathrm{HCO}_{3}^{-}$yang rendah akibat tidak adanya kontak dengan batuan gamping sehingga berakibat terhadap rerata tahunan nilai konsentrasi $\mathrm{HCO}_{3}^{-}$yang rendah di SBT Gua Anjani. Konsentrasi $\mathrm{HCO}_{3}^{-}$yang meng-input SBT Gua Anjani hanya memiliki nilai yang berkisar antara 0,09 hingga $0,19 \mathrm{~g} / \mathrm{l}$. 


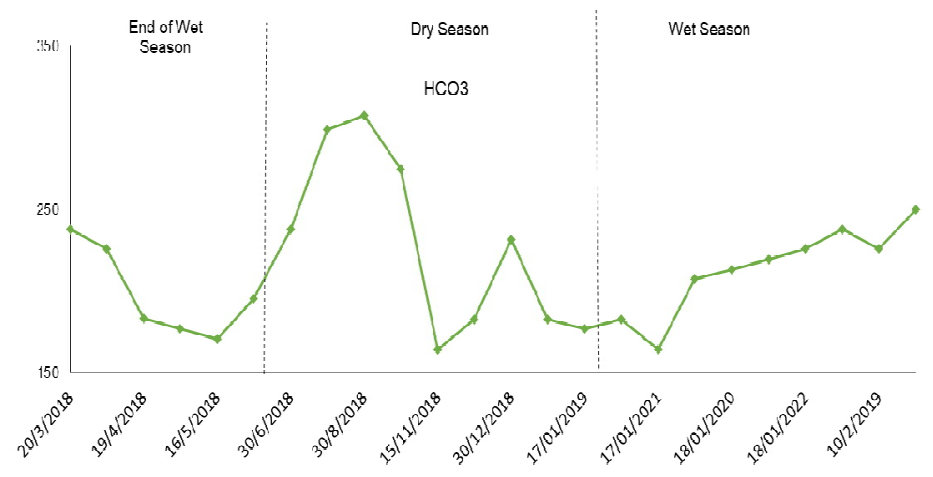

\section{Kesimpulan}

Temuan dari penelitian ini dapat disimpulkan sebagai berikut: (1) SBT Gua Anjani memiliki tingkat pelarutan mineral $\mathrm{CaCO}_{3}$ sebesar $48,10 \mathrm{~m}^{3} / \mathrm{tahun} / \mathrm{km}^{2}$. Beberapa faktor yang berpengaruh di antaranya adalah total debit aliran, kandungan $\mathrm{CO}_{2}$ terlarut, suhu aliran, dan $\mathrm{pH}$. Total debit aliran SBT Gua Anjani mencapai 4,82 x10 $\mathrm{m} 3 / \mathrm{s}$. Debit aliran di SBT Gua Anjani dipengaruhi oleh sungai Allogenic Kali Cebong, Jumbleng Sawah, dan Kali Setro yang masing-masing debitnya adalah $1,6 \times 10^{6} \mathrm{~m}^{3} /$ tahun, $0,58 \times 10^{6} \mathrm{~m}^{3} /$ tahun, dan $0,55 \times 10^{6} \mathrm{~m}^{3} /$ tahun. Kandungan $\mathrm{CO}_{2}$ terlarut berkisar antara $-2,53$ hingga $-1,29$, suhu aliran sebesar 23,26, dan $\mathrm{pH}$ yang cenderung basa, yaitu 7,42. (2) Laju penyerapan karbon dioksida atmosfer di SBT Gua Anjani mencapai 70,50 ton/tahun $/ \mathrm{km}^{2}$. Faktor-faktor yang berpengaruh adalah debit aliran dan konsentrasi $\mathrm{HCO}_{3}{ }^{-}$. Debit aliran mencapai 944998856,2 1/tahun. Debit aliran di SBT Gua Anjani juga dipengaruhi oleh luas DTA, diketahui luas DTA Anjani mencapai $4 \mathrm{~km}^{2}$. Rerata konsentrasi $\mathrm{HCO}_{3}{ }^{-} \mathrm{SBT}$ Gua Anjani mencapai $0,21 \mathrm{~g} / \mathrm{l}$. Konsentrasi $\mathrm{HCO}_{3}$ 'sangat dipengaruhi musim. Ketika musim hujan, Konsentrasi $\mathrm{HCO}_{3}{ }^{-}$cenderung rendah dan ketika musim kemarau cenderung tinggi. Selain musim, keberadaan sungai allogenic yang mengimbuh SBT Gua Anjani juga memengaruhi rendahnya konsentrasi $\mathrm{HCO}_{3}^{-}$

\section{Persembahan}

Penulis ingin mengucapkan terima kasih kepada Fakultas Geografi Universitas Gadjah Mada atas dukungannya untuk melakukan penelitian ini baik dalam tahap persiapan, lapangan, maupun penulisan; penulis juga berterima kasih kepada warga Desa Tlogoguwo atas dukungan dan bantuannya selama pengumpulan data di lapangan.

\section{Referensi}


[1] IPCC, Mitigation of climate change: Contribution of working group III to the fourth assessment report of the Intergovernmental Panel on Climate Change. New York: Cambridge University Press, 2007.

[2] Daoxian, Y., The Carbon Cycle in Karst, Zeitschrift f Geomorph, vol. 108, pp. 91-102, 1997.

[3] Haryono, E., Atmospheric carbon dioxide sequestration through karst denudation processes, in Asian trans-disciplinary Karst Conference, 2011

[4] Liu., and Zhao, J., Contribution of carbonate rock weathering to the atmospheric CO2 sink, Environ. Geol., vol. 39, no. 9, pp. 1053-1058, 2000.

[5] Ciais, P., C. Sabine, G. Bala, L. Bopp, V. Brovkin, J. Canadell, A. Chhabra, R. DeFries, J. Galloway, M. Heimann, C. Jones, C. Le Quéré, R. B. Myneni, S. Piao and P. Thornton, 2013: Carbon and Other Biogeochemical Cycles. In: Climate Change 2013: The Physical Science Basis. Contribution of Working Group I to the Fifth Assessment Report of the Intergovernmental Panel on Climate Change [Stocker, T. F., D. Qin, G.-K. Plattner, M. Tignor, S. K. Allen, J. Boschung, A. Nauels, Y. Xia, V. Bex and P. M. Midgley (eds.)]. Cambridge University Press, Cambridge, United Kingdom and New York, NY, USA

[6] Junbing, P., Zhongcheng, J., Daoxian, Y., Some opinions on rock-weathering-related carbon sinks from the IPCC Fifth Assessment Report, Adv. Earth Sci., vol. 30, no. 10, pp. 10811090, 2015.

[7] Van Bemmelen, R.W., The Geology of Indonesia Vol.IA: General Geology of Indonesia and Adjacent Archipelagoes. The Hauge: Government Printing Office, 1949.

[8] Hartono, H.G., and Sudradjat, A., Nanggulan Formation and Its Problem As a Basement in Kulonprogo Basin, Yogyakarta, Indones. J. Geosci., vol. 4, no. 2, pp. 71-80, 2017

[9] Widagdo, A., Pramumijoyo, S., Harijoko, A., Morphotectono-volcanic of Tertiary volcanic rock in Kulon Progo mountains area , Yogyakarta-Indonesia, Earth Environ. Sci., vol. 212, 2018.

[10] Fetter, C.W., Applied Hydrogeology. New Jersey: prentice-hall, inc, 1994.

[11] Waskito, W.A., Studi Hidrograf Aliran Mataair Untuk Karakterisasi Akuifer di Kawasan Karst Jonggrangan, Unpublished thesis, Fakultas Geografi, Universitas Gadjah Mada, 2018.

[12] Todd, D.K., Groundwater Hydrology. New York: John Wiley \& Sons, 1980.

[13] Suripin, Pelestarian Sumber Daya Tanah dan Air. Yogyakarta: ANDI, 2002.

[14] Kresic, Water in Karst ; Management, Vulnerability, and Restoration. New York: McGrawHill, 2013.

[15] Agniy, R.F., Adji, T.N., Cahyadi, A., Nurkholis, A., Haryono, E.,Characterizing the cavities of Anjani Cave in Jonggrangan Karst Area, Purworejo, Central Java, Indonesia, IOP Conf. Series:Earth and Environmental Science 256 (2019) 012011 doi:10.1088/17551315/256/1/012011, 2019

[16] Nurkholis, A., Adji, T.N., Haryono, E., Cahyadi, A., Waskito, W.A., Fatoni, A., Kurniawan, I.A., Agniy, R.F., 2019, Analysis of Master Recession Curve (MRC) and flood hydrograph components for karstification degree estimation in Kiskendo Cave, Jonggrangan Karst System, Indonesia, IOP Conf. Series: Earth and Environmental Science 256 (2019) 012011, doi:10.1088/1755-1315/256/1/012011, 2019

[17] Kurniawan, I.A., Adji, T.N., Nurkholis, A., Haryono, E., Fatoni, H., Waskito, W.A., Cahyadi, A., Agniy, R.F., Karst aquifer response by time series analysis applications in Jonggrangan Karst, Java Island, Indonesia, Environmental Earth Sciences, 76:709, doi: 10.1007/s12665019-8386-x, 2019 
[18] Adji, T.N., Haryono, E., Fatchurohman, H., Oktama, R, 2017, Spatial and temporal hydrochemistry variations of karst water in Gunung Sewu, Java, Indonesia, Environmental Earth Sciences, 76:709, https://doi.org/10.1007/s1266 5-017-7057-z 